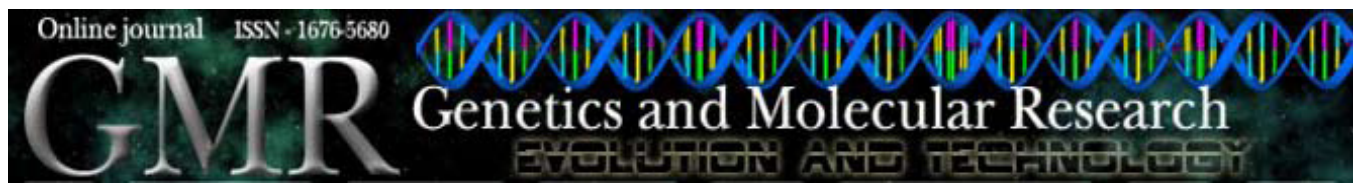

\title{
Production of workers, queens and males in Plebeia remota colonies (Hymenoptera, Apidae, Meliponini), a stingless bee with reproductive diapause
}

\author{
D.A. Alves ${ }^{1}$, V.L. Imperatriz-Fonseca ${ }^{1,2}$ and P.S. Santos-Filho ${ }^{1}$ \\ ${ }^{1}$ Departamento de Ecologia, Instituto de Biociências, \\ Universidade de São Paulo, São Paulo, SP, Brasil \\ ${ }^{2}$ Departamento de Biologia, Faculdade de Filosofia, \\ Ciências e Letras de Ribeirão Preto, Universidade de São Paulo, \\ Ribeirão Preto, SP, Brasil \\ Corresponding author: D.A. Alves \\ E-mail: daalves@ib.usp.br
}

Genet. Mol. Res. 8 (2): 672-683 (2009)

Received December 12, 2008

Accepted January 26, 2009

Published June 9, 2009

\begin{abstract}
Queen, male and worker production was studied during one year in three Plebeia remota colonies from Atlantic Rainforest in Cunha, São Paulo State, and two from a subtropical Araucaria forest in Prudentópolis, Paraná State. All the colonies were kept in São Paulo city during our study. Plebeia remota has reproductive diapause during autumn and winter, which makes its biology of special interest. Brood production begins before spring, renewing the colony cycle. We sampled brood combs monthly in these five colonies. The number of cells in each comb varied
\end{abstract}


significantly with time of the year; the smallest brood combs appear to be a consequence of reduced food availability. However, worker, queen and male frequencies did not differ significantly in time, and this presumably is due to the fact that they all are necessary for the growth, maintenance and reproduction of the colony. Although some molecular, morphological and behavioral differences have been detected in several studies comparing populations from Cunha and from Prudentópolis, we did not find significant differences between the colonies from these two localities in number of brood cells and worker, queen and male production.

Key words: Plebeia remota; Stingless bees; Queen production; Worker production; Male production

\section{INTRODUCTION}

Although the biology of stingless bees (Meliponini) is similar to that of honey bees (Apini), they also possess many unique features, mainly related to reproduction. One of them is the number of males that the mother queen mates with. In honey bees, queens mate with 10 or more males, but in the Meliponini single mating is the rule (Peters et al., 1999; Strassmann, 2001). Other major differences exist in the way that brood cells are provisioned. In stingless bees, cells are mass provisioned, whereby each brood cell is filled with liquid larval food regurgitated by the workers, after which the queen deposits an egg into the cell, and the workers close it. In this way, the larvae have all the food available necessary for their entire development without requiring any further contact with the adult workers. By contrast, in Apis honey bees, larvae are fed progressively by the workers in open cells (Sakagami, 1982).

Caste determination in stingless bees is also more variable than in honey bees. In the majority of stingless bee genera, except for Melipona, queens are reared in royal cells that are bigger than the other cells. In these cases, caste is trophogenically determined, as is also the case in honey bees, because queen-destined larvae receive a greater amount of larval food than the workers and males. However, in some species, including Cephalotrigona capitata (von Ihering, 1903), Nannotrigona testaceicornis (Imperatriz-Fonseca et al., 1997), Plebeia julianii (Juliani, 1967), P. pugnax (Ribeiro et al., 2006), P. remota (Ribeiro et al., 2003a, 2006), and Schwarziana quadripunctata (Camargo, 1974; Ribeiro and Alves, 2001; Ribeiro et al., 2006), queens may be reared in both royal cells and small cells (for a review, see Ribeiro et al., 2006). The latter are smaller than normal queens, since they emerge from brood cells in which normally only workers and males are reared. Just like normal queens, however, miniature queens can successfully mate and head colonies (Ribeiro and Alves, 2001). Finally, in Melipona, queens and workers are produced in identically sized cells, and are typically produced in great excess of colony needs (Kerr, 1950; Ratnieks, 2001; Wenseleers et al., 2003). The ultimate reasons for the great variation in the way that queens are reared in stingless bees are currently a very active area of study (see Wenseleers et al., 2003, Ribeiro et al., 2006).

Common to both honey bees and stingless bees, as well as all other haplodiploid 
eusocial insects, is that the queen can control the sex of the eggs she lays via the controlled release of sperm stored in her spermatheca, whereby fertilized eggs give rise to females (queens or workers) and unfertilized eggs give rise to males (Hamilton, 1964a,b). The workers, in contrast, cannot mate, but usually retain the ability to lay unfertilized, male eggs. This causes a conflict between the mother queen and the workers, as each are most related to their own sons, and so would like to produce the colony's males (for revision, see Mehdiabadi et al., 2003; Tóth et al., 2004). In honey bees, worker reproduction is usually quite rare (Ratnieks, 1993), but in stingless bees it can be frequent, not only in queenless colonies but also in the presence of the mother queen (Sakagami et al., 1963; Beig, 1972; Bego, 1982, 1990; Koedam et al., 1999; Tóth et al., 2002, 2004).

Many studies have been conducted in an attempt to determine the ultimate reasons that cause this great variation in reproductive patterns in stingless bees, particularly on the genus Melipona. These studies are concerned both with the mechanisms of caste determination, as well as male maternity. However, relatively little attention has been given to worker production and the ergonomics of colony growth. Greater knowledge about these factors would enable us to better understand the mechanisms of maintenance and growth of the colony, and how worker and sexual production should be traded off against each other (Reuter and Keller, 2001).

In this context we examined queen, male and worker production over one full year in two populations of the stingless bee Plebeia remota, from Cunha, São Paulo State, and from Prudentópolis, Paraná State. We chose this species for three main reasons. The first concerns the way that the queens are reared, in royal cells and in cells with similar size used for rearing workers and males. The second reason concerns the molecular and behavioral evidence that suggests that $P$. remota from Cunha is different from what is found in Prudentópolis (Ribeiro et al., 2003b; Francisco et al., 2008). And the third concerns the period, between autumn and winter, of reduced activity (van Benthem et al., 1995), called reproductive diapause (Ribeiro et al., 2003b), which is an adaptation to unfavorable environmental conditions, and its consequences on seasonal brood production.

\section{MATERIAL AND METHODS}

We used three Plebeia remota nests from Cunha, São Paulo State $\left(23^{\circ} 05^{\prime}\right.$ S, $\left.44^{\circ} 55^{\prime} \mathrm{W}\right)\left(\mathrm{C} 1, \mathrm{C} 2\right.$, and C3) and two from Prudentópolis, Paraná State (25 $13^{\circ} \mathrm{S}$, $50^{\circ} 59^{\prime} \mathrm{W}$ ) ( $\mathrm{P} 1$ and $\mathrm{P} 2$ ). All the colonies were kept in wooden observation boxes in the Bee Laboratory of the Bioscience Institute, São Paulo University (233' 'S, $\left.46^{\circ} 43^{\prime} \mathrm{W}\right)$, in São Paulo city. The colonies were covered with glass lids to allow observation of the inside of the nests. In addition, the colonies were connected with the exterior of the laboratory using a plastic tube, so that the workers could forage freely for food and dispose of their garbage.

Once a month, we sampled old brood combs from the colonies, containing bees ready to emerge or pupae with pigmented eyes, to evaluate worker, queen and male production. Sometimes, if the comb was positioned at the bottom of the box and sampling would have required intense manipulation, or if the comb was very small ( $<40$ cells), we chose not to collect it. For this reason, not all the colonies were analyzed every month.

To count the number of individuals present in the collected combs, we opened all 
cells of the combs with an entomological pin. Subsequently, the morphological characteristics of the heads were used in order to distinguish the sex (male or female) and caste (queen or worker) of each individual. Finally, we returned the combs to their mother colonies, after which the workers repaired them with a cerumen layer so that all individuals could still emerge in their natal colony.

We analyzed 37 brood combs during two periods, from February to June 2003 $(\mathrm{N}=18$ combs $)$ and from October 2003 to January $2004(\mathrm{~N}=19 \mathrm{combs})$. The gap between these two periods corresponds to the reproductive diapause that occurs in autumn and winter in this species (van Benthem et al., 1995; Ribeiro et al., 2003b). In June, the colonies were already in diapause, and the sampled combs were the last ones that were produced in the nests. The combs sampled in October correspond to the first ones that were constructed after the end of the diapause period.

To analyze our data, we utilized the Kruskal-Wallis test, using the test statistic $K$ when we compared more than two groups. We also used Spearman correlations; P values smaller than 0.05 were considered to be significant.

\section{RESULTS}

Over the whole one-year period, we collected 37 brood combs from five P. remota colonies from the two populations examined. Overall, these contained 11,184 individuals, of which $73.40,26.52$ and $0.08 \%$ were workers, males and queens, respectively. Among all the female brood produced $(\mathrm{N}=8218), 0.11 \%$ were queens, all but one of which were reared in large, royal cells. Overall, $26.60 \%$ of the individuals produced were sexuals (males or queens).

\section{Number of brood cells}

The brood combs had ample variation in size, from 41 to 826 cells $(302.27 \pm$ 170.63 cells $)$. The brood combs collected in colonies from Cunha $(\mathrm{N}=23 \mathrm{combs})$ had $320.78 \pm 182.41$ cells (minimum: 97; maximum: 826 cells), whereas those collected in colonies from Prudentópolis $(\mathrm{N}=14$ combs) had 271.86 \pm 150.72 cells (minimum: 41; maximum: 546 cells). We did not find significant differences between cell number in combs from Cunha versus Prudentópolis $(\mathrm{H}=0.769 ; \mathrm{P}=0.381)$.

Also, we did not find significant differences between comb sizes from the different colonies $(\mathrm{K}=5 ; \mathrm{H}=1.479 ; \mathrm{P}=0.830)$. The combs from colonies $\mathrm{C} 1, \mathrm{C} 2, \mathrm{C} 3$, and P1 were similar in mean size, but the combs sampled from colony P2 were the smallest (Table 1).

The largest combs were sampled in February (552.00 \pm 137.27 cells) and December $(478.60 \pm 57.50$ cells $)$, while the smallest were collected in June $(157.50 \pm 25.32$ cells $)$ and October $(89.83 \pm 15.68$ cells $)$. The number of cells varied significantly with time of the year $(\mathrm{K}=9 ; \mathrm{H}=28.203 ; \mathrm{P}<0.001)$.

There was a significant correlation between the number of cells and the number of individuals produced. We found a positive correlation between the number of cells and the number of workers $(\mathrm{r}=0.851 ; \mathrm{P}<0.001$; Figure 1$)$ and between the number of cells and the number of males $(\mathrm{r}=0.717$; $\mathrm{P}<0.001$; Figure 1$)$. This means that bigger combs produced 
Table 1. Mean relative frequency (\%) of queens, workers and males produced and respective standard deviations (SD), minimum frequencies (min.) and maximum frequencies (max.) in Plebeia remota colonies, between February 2003 and January 2004.

\begin{tabular}{|c|c|c|c|c|c|}
\hline & \multicolumn{3}{|c|}{ Cunha } & \multicolumn{2}{|c|}{ Prudentópolis } \\
\hline & $\mathrm{C} 1$ & $\mathrm{C} 2$ & $\mathrm{C} 3$ & $\mathrm{P} 1$ & $\mathrm{P} 2$ \\
\hline \multicolumn{6}{|c|}{ Relative frequency (\%) } \\
\hline \multicolumn{6}{|c|}{ Queens } \\
\hline mean & 0.10 & 0.22 & 0.00 & 0.26 & 0.34 \\
\hline $\mathrm{SD}$ & 0.24 & 0.41 & 0.00 & 0.59 & 0.69 \\
\hline $\min$. & 0.00 & 0.00 & 0.00 & 0.00 & 0.00 \\
\hline $\max$ & 0.60 & 1.03 & 0.00 & 1.32 & 2.04 \\
\hline \multicolumn{6}{|l|}{ Workers } \\
\hline mean & 89.95 & 80.50 & 70.62 & 78.08 & 75.61 \\
\hline $\mathrm{SD}$ & 16.57 & 15.59 & 26.96 & 24.46 & 20.64 \\
\hline $\min$. & 60.23 & 63.71 & 34.98 & 46.22 & 41.06 \\
\hline $\max$ & 100.00 & 99.48 & 99.18 & 98.68 & 100.00 \\
\hline \multicolumn{6}{|l|}{ Males } \\
\hline mean & 9.95 & 19.29 & 29.38 & 21.65 & 24.05 \\
\hline $\mathrm{SD}$ & 16.64 & 15.81 & 26.96 & 24.74 & 20.71 \\
\hline $\min$. & 0.00 & 0.00 & 0.82 & 0.00 & 0.00 \\
\hline $\max$ & 39.77 & 36.29 & 65.02 & 53.78 & 58.17 \\
\hline \multicolumn{6}{|c|}{ Absolute frequency } \\
\hline \multicolumn{6}{|c|}{ Brood cells } \\
\hline mean & 330.67 & 315.50 & 318.89 & 316.40 & 247.11 \\
\hline $\mathrm{SD}$ & 202.50 & 152.56 & 213.08 & 167.18 & 144.95 \\
\hline $\min$. & 109.00 & 97.00 & 122.00 & 76.00 & 41.00 \\
\hline $\max$ & 648.00 & 504.00 & 826.00 & 546.00 & 425.00 \\
\hline total & 1984.00 & 2524.00 & 2870.00 & 1582.00 & 2224.00 \\
\hline Queens & 1.00 & 2.00 & 0.00 & 1.00 & 5.00 \\
\hline Workers & 1683.00 & 1922.00 & 1951.00 & 1126.00 & 1527.00 \\
\hline Males & 300.00 & 600.00 & 919.00 & 455.00 & 692.00 \\
\hline Brood combs & 6.00 & 8.00 & 9.00 & 5.00 & 9.00 \\
\hline
\end{tabular}

The absolute frequencies of brood cells, queens, workers, males, and brood combs analyzed in colonies from Cunha $(\mathrm{C} 1, \mathrm{C} 2$, and C3) and from Prudentópolis (P1 and P2) are given.

more workers and males. The relationship between the number of cells and the number of queens was negative and significant ( $r s=-0.369 ; \mathrm{P}=0.025$ ), although we found a low frequency of this caste. This result could be due to the fact that these queens were reared in small combs, with a mean size of $181.29 \pm 124.41$ cells, varying from 98 to 425 cells.

\section{Worker production}

Workers were found in all brood combs; however, their frequencies were below $40 \%$ in two samples, because of intense male production. In four combs (10.81\% of the samples), we found only workers. The percentage of workers varied from 34.98 to $100 \%$ of workers $(78.11 \pm 21.17 \%)$.

Worker production by colonies from Cunha did not differ from those from Prudentópolis $(\mathrm{H}=0.454 ; \mathrm{P}=0.501)$. June and October 2003 were the months with the highest proportion of workers (Table 2). These periods corresponded to the last combs constructed before reproductive diapause and to the first combs after this phase, respectively (Table 2). 


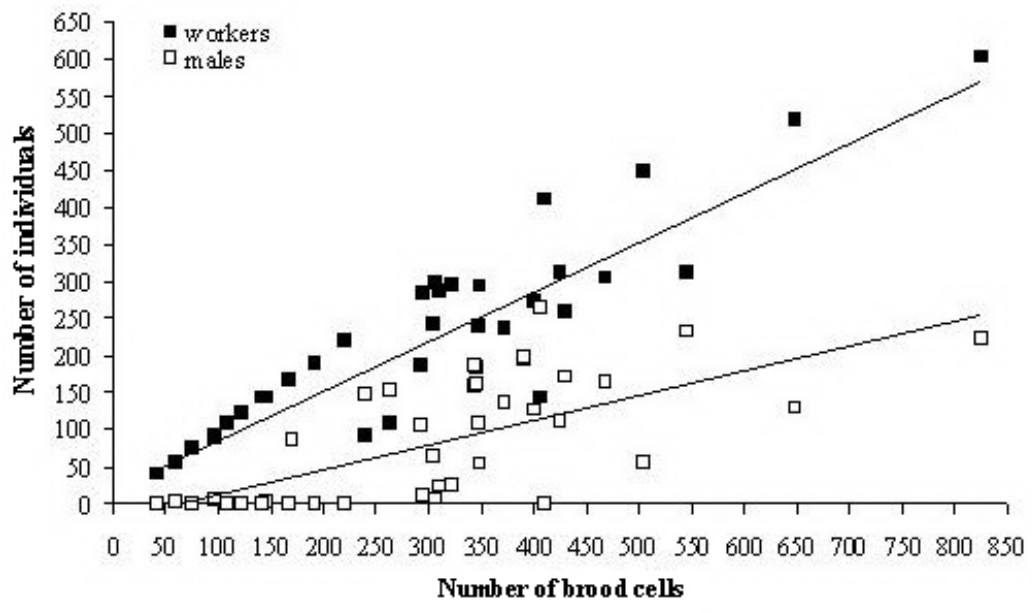

Figure 1. Correlation between the number of brood cells and the number of individuals (workers and males) in 37 brood combs sampled from Plebeia remota colonies.

\begin{tabular}{|c|c|c|c|c|c|c|c|c|c|c|c|c|}
\hline \multirow{2}{*}{$\begin{array}{l}\text { Relative } \\
\text { frequency } \\
(\%)\end{array}$} & \multicolumn{12}{|c|}{ Months } \\
\hline & Feb & Mar & Apr & May & Jun & Jul & Aug & Sep & Oct & Nov & Dec & Jan \\
\hline \multicolumn{13}{|l|}{ Queens } \\
\hline mean & 0.00 & 0.15 & 0.00 & 0.00 & 0.81 & * & * & * & 0.42 & 0.00 & 0.05 & 0.00 \\
\hline SD & 0.00 & 0.34 & 0.00 & 0.00 & 0.87 & * & * & * & 0.53 & 0.00 & 0.11 & 0.00 \\
\hline $\min$. & 0.00 & 0.00 & 0.00 & 0.00 & 0.00 & * & * & * & 0.00 & 0.00 & 0.00 & 0.00 \\
\hline $\max$. & 0.00 & 0.76 & 0.00 & 0.00 & 2.04 & * & * & * & 1.32 & 0.00 & 0.24 & 0.00 \\
\hline \multicolumn{13}{|l|}{ Workers } \\
\hline mean & 67.12 & 67.96 & 70.39 & 70.95 & 97.80 & * & * & * & 97.15 & 69.51 & 74.68 & 75.01 \\
\hline SD & 6.40 & 29.32 & 25.94 & 30.17 & 2.76 & * & * & * & 3.61 & 19.61 & 15.34 & 26.87 \\
\hline $\min$. & 60.23 & 41.06 & 38.49 & 49.62 & 93.88 & * & * & * & 90.72 & 49.41 & 57.33 & 34.98 \\
\hline $\max$. & 72.88 & 100.00 & 100.00 & 92.28 & 100.00 & * & * & * & 100.00 & 96.26 & 97.39 & 91.93 \\
\hline \multicolumn{13}{|l|}{ Males } \\
\hline mean & 32.88 & 31.89 & 29.61 & 29.05 & 1.54 & * & * & * & 2.34 & 30.49 & 25.27 & 24.99 \\
\hline SD & 6.40 & 29.15 & 25.94 & 30.17 & 1.96 & * & * & * & 3.48 & 19.61 & 15.34 & 26.87 \\
\hline $\min$. & 27.12 & 0.00 & 0.00 & 7.72 & 0.00 & * & * & * & 0.00 & 3.74 & 2.61 & 8.07 \\
\hline $\max$ & 39.77 & 58.17 & 61.51 & 50.38 & 4.08 & * & * & * & 8.25 & 50.59 & 42.67 & 65.02 \\
\hline Brood cells & 1656 & 1554 & 1025 & 702 & 630 & * & * & * & 539 & 1104 & 2393 & 1581 \\
\hline Brood combs & 3 & 5 & 4 & 2 & 4 & * & * & * & 6 & 4 & 5 & 3 \\
\hline
\end{tabular}

The absolute frequencies of brood cells and brood combs analyzed monthly are given. *Months without samples due to reproductive diapause period.

When we compared the frequencies of workers produced monthly, we did not find significant differences among them $(\mathrm{K}=9 ; \mathrm{H}=12.435 ; \mathrm{P}=0.133)$ nor between the frequencies of workers produced before and after diapause $(\mathrm{H}=0.067 ; \mathrm{P}=0.796)$.

The mean frequencies of workers in colonies $\mathrm{C} 1$ and $\mathrm{C} 2$ were higher than $80 \%$, whereas 
the lowest was found in colony $\mathrm{C} 3$ (Table 2), although this nest produced the most of males. In absolute frequencies, colonies $\mathrm{C} 1, \mathrm{C} 2$ and $\mathrm{C} 3$ contributed more workers to the population, which corresponded to, 20.50, 23.41 and $23.77 \%$, respectively, of sampled workers, than the other colonies. However, when we compared the frequencies of workers produced, there were no significant differences among the colonies $(\mathrm{K}=5 ; \mathrm{H}=5.110 ; \mathrm{P}=0.276)$.

\section{Queen production}

We found few queens $(\mathrm{N}=9)$ in the brood combs; in $81.09 \%$ of them, queens were absent. Eight of the nine queens were reared in royal cells $(88.89 \%)$. Only one queen was found in a cell with similar size with those where workers and males are reared. We did not find significant differences in queen production between the localities $(\mathrm{H}=1.530 ; \mathrm{P}=0.216)$, though colonies from Prudentópolis had produced $66.66 \%$ of the queens ( $\mathrm{N}=6$ queens).

The queens were produced only in March, June, October, and December 2003 (Table 2). However, their frequency did not vary significantly in relation to the month of the year $(\mathrm{K}=9 ; \mathrm{H}$ $=10.510 ; \mathrm{P}=0.231)$. The highest proportions were found in June (33.33\% of the queens) and October (33.33\% of the queens) (Figure 2), corresponding to the last combs built before reproductive diapause and to the first combs built after this period, respectively. However, when we compare the period before and after this phase of inactivity, we did not find significant difference $(H=0.084$; $\mathrm{P}=0.773$ ).

Colony C3 did not produce any queens in nine sampled combs. However, with the same number of brood combs, we found five queens in colony P2 (55.56\% of the queens). Nevertheless, we did not find difference among the colonies $(\mathrm{K}=5 ; \mathrm{H}=3.463 ; \mathrm{P}=0.484)$, when we compared the relative frequencies of queens in brood combs.

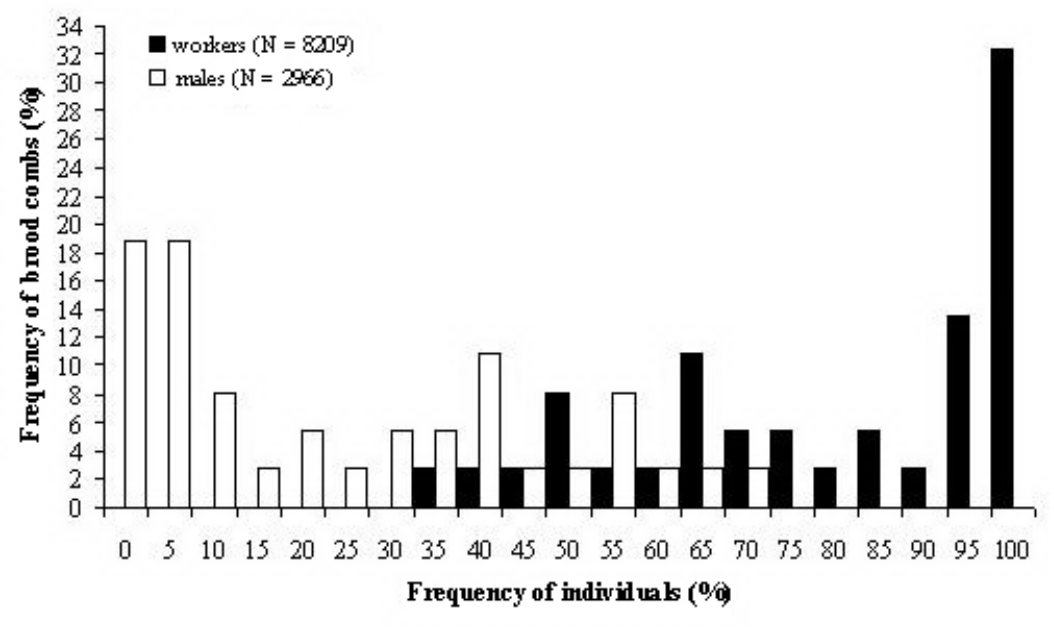

Figure 2. Relative frequency distributions (\%) of workers and males in Plebeia remota brood combs. $\mathrm{N}=$ total number of individuals observed. 


\section{Male production}

Among 2966 sampled males, only two had been reared in royal cells ( $0.07 \%$ of males). One was found in May in colony P2 and another in November in nest C2. Among the 10 individuals reared in royal cells, the giant males corresponded to $20 \%$ of them.

In $18.92 \%$ of the samples, males were absent (Figure 2). However, in $16.22 \%$ of the combs, the male percentages were superior to $50 \%$ of the individuals. Among these combs with many males, only one had two queens; in another five combs, males and workers were produced. There was ample variation $(0-65.02 \%$ males $)$; the mean was $21.71 \pm 21.27 \%$ males When we compare male frequencies, we did not find significant differences between colonies from Cunha and from Prudentópolis $(\mathrm{H}=0.320 ; \mathrm{P}=0.572)$.

In February, March and November 2003 there were more than 30\% males (Table 2). The brood combs collected in June and October had the lowest average frequencies, with 1.54 $\pm 1.96 \%$ and $2.34 \pm 3.48 \%$ males, respectively. On the other hand, these combs were composed almost entirely by workers, since they were the last ones before the period of cell construction stop and the first ones after this period of reproductive inactivity. When we compared the male frequencies in different months, we did not find significant differences among them $(\mathrm{H}=$ 13.859; $\mathrm{P}=0.086)$, nor inter-colony differences $(\mathrm{K}=5 ; \mathrm{H}=4.829 ; \mathrm{P}=0.305)$, even though colony $\mathrm{C} 3$ was responsible for $30.98 \%$ of the males sampled during the study period (Table 1 ).

\section{DISCUSSION}

Differences between P. remota colonies from Cunha and Prudentópolis have been reported in some studies, suggesting that they are two species. These differences concern architectural aspects of the nests, duration of reproductive diapause (Ribeiro et al., 2003b), workers' and queens' Dufour secretions, queen's scutellum (Patrício and Imperatriz-Fonseca, 2004), wing venation patterns, mitochondrial DNA patterns analyzed via PCR + RFLP, cuticular hydrocarbons, and DNA microsatellite analyses (Francisco et al., 2008). However, we did not find significant differences between colonies from Cunha and from Prudentópolis in the number of brood cells and worker, queen and male production.

Worker, queen and male production did not differ significantly before and after reproductive diapause, or in the different months. These results indicated that workers, queens and males are present at population level in the whole year.

\section{Number of brood cells}

The number of brood cells could be a direct consequence of the colony state, such as population density and food supply. In stronger colonies, we found larger brood combs due to greater activity in cell construction, whereas in weaker colonies, the number of cells in construction was lower, so the combs were smaller. In accordance with Bego (1990), the colonies pass for different moments in which they are strong and subsequently they become weak, and each colony has an optimum to be reached. This cycle can explain the significant difference in the numbers of cells according to the time of the year.

van Benthem et al. (1995) observed that the P. remota combs from weak colonies had from 100 to 350 cells, while combs from strong colonies had 550 to 850 cells, similar to what 
we found. The authors concluded that the number of cells is proportional to the population of adult workers, responsible for the different tasks in the nest. The smallest combs that we encountered in $P$. remota colonies, with less than 100 cells, could be a consequence of insufficient food supplies. Similar results were found for Scaptotrigona postica (Bego, 1990) and for Trigona ventralis (Chinh and Sommeijer, 2005). In the latter species, there is a significant correlation $(\mathrm{P}=0.036)$ between the number of food pots and the number of brood cells, and during the dry season the amount of food stored in the nest and the comb size were smaller than during the wet season. In S. postica, Bego $(1982,1990)$ attributes the variation in comb sizes to intrinsic relations of various extra- and intra-colonial factors. She emphasizes, as do Chinh and Sommeijer (2005), that during the rainy period, colony growth rate raises, owing to an ample quantity of pollen and nectar from flowers.

The positive relationship between the number of brood cells and the number of individuals produced was also found by Santos-Filho et al. (2006) for species that build royal cells ( $P$. remota and Schwarziana quadripunctata). These authors indicate that there is strict control over the allocation to workers, due to their ergonomic function to the colony (Oster and Wilson, 1978). The positive relationship between comb size and male production can be explained by the investment in reproductives, since investment in gynes for $P$. remota colonies was very low (see Santos-Filho et al., 2006).

\section{Worker production}

Workers were presented in all sampled combs, and this demonstrates their fundamental importance for the functioning of the colony as a whole, due to many tasks performed by them involving the growth and maintenance of the nest (Oster and Wilson, 1978). Some combs were composed basically of workers, whereas some had values below $40 \%$. Santos-Filho et al. (2006) interpreted these low values as a minimum threshold for the survivorship of the colony.

The highest percentages of workers were found in June and October, accounting for 98.41 and $97.22 \%$ of the individuals produced, respectively. During these months, the sampled combs were the last combs constructed before reproductive diapause and the first combs after this phase. This phenomenon corresponds to interruption of brood cell construction by workers and consequently, the mated queen stops laying eggs (van Benthem et al., 1995; Ribeiro et al., 2003b). Therefore, workers are needed during this phase of reduced activity in order to conduct other tasks in the colony, such as foraging (Hilário, 2005). Because they are the last ones to emerge in the nest, these workers have a longer longevity than those produced in the other months (van Benthem et al., 1995), and they are responsible to build brood cells when reproductive diapause ceases.

\section{Queen production}

The low frequency of queens $(0.08 \%$ of the individuals) that we found in P. remota colonies was similar to what has been reported for other species that rear their queens only in royal cells, the typical queens, such as in T. ventralis (166 queens in 205,536 cells) (Chinh and Sommeijer, 2005). During 21 months of study, Bego (1990) evaluated 129,000 brood cells from $S$. postica colonies and found approximately $0.05 \%$ royal cells. In three $S$. bipunctata 
colonies, 1472 cells were recorded; only $0.27 \%$ corresponded to queens reared in royal cells (Alves DA, Wenseleers T and Imperatriz-Fonseca VL, unpublished results).

Nannotrigona testaceicornis and S. quadripunctata, which have both systems of queen production (in royal cells and in normal-sized cells), have low investments in queens similar to those of species that rear their queens only in royal cells. The annual queen production recorded in $N$. testaceicornis was $0.01 \%$ (Cabral and Imperatriz-Fonseca, 2007) and it was $0.56 \%$ in S. quadripunctata (Wenseleers et al., 2005). However, exceptionally high queen production can occasionally occur and this phenomenon was reported for Cephalotrigona capitata $(\mathrm{N}=20$; von Ihering, 1903), $N$. testaceicornis $(\mathrm{N}=9$ queens, in a small piece of comb; Imperatriz-Fonseca et al., 1997) and $S$. quadripunctata $(\mathrm{N}=29$; Camargo, 1974). Ribeiro et al. (2003a) recorded within two months 46 queens in a $P$. remota colony and another 21 queens emerged from a comb with 40 cells. The great majority of these queens were miniature and their high production implies some costs for the colonies (Wenseleers et al., 2003). This was an isolated event and is very uncommon.

The production of miniature queens can be explained by the caste conflict hypothesis. It assumes that selfish females reared in normal-sized cells become queens, instead of workers, because they have direct benefits in reproduction (Ratnieks, 2001; Wenseleers et al., 2003, 2005). We encountered only $0.01 \%$ miniature queens among 8210 females reared in normal-sized cells.

Although we did not find significant differences among months, the queens were produced in higher proportions in June and October. All were recorded in royal cells and this fact indicates that the workers construct these special cells to assure the survival of the colony during unfavorable environmental conditions. If the mated queen dies during reproductive diapause, there are new queens in the nest to be selected by workers, which can mate and replace the dead one, thus the future of the colony is assured.

\section{Male production}

The occurrence of giant males is relatively common in Meliponini species, including Friesella schrottkyi (Camillo, 1971), P. julianii (Juliani, 1967), S. postica (Bego and Camargo, 1984), and S. quadripunctata (Santos-Filho et al., 2006). Camillo (1971) found that $F$. schrottkyi giant males have 2.35 times more spermatozoids than males emerged from normalsized cells. Some authors have suggested that they are produced during male-producing periods, because workers cannot distinguish royal cells from normal-sized cells when they are laying reproductive eggs (Camillo, 1971; Bego and Camargo, 1984). However, another possibility would be that if these males are queens' sons, the queen can decide if she will fertilize the egg or not during oviposition. Because the royal cells have a larger diameter, the mated queen could perceive this and lay a haploid egg. Thus, she would avoid future competition with her daughter and to be replaced by it. However, this hypothesis needs to be tested; this could be done with molecular tools.

In a 4.5-month study of combs from $P$. remota, there was an ample variation in male production, from complete absence to high frequencies, with up to $70 \%$ males (van Benthem et al., 1995). We also found a wide variation in male frequency in combs, from 0 to $65.02 \%$ of males.

Other studies have reported similar variations, such as in S. quadripunctata $(0-100 \%$; Alves and Imperatriz-Fonseca, 2005), S. postica (Bego, 1990), Tetragonisca angustula (Grosso et al., 2000), and T. ventralis (0-100\%; Chinh and Sommeijer, 2005). Velthuis et al. (2005) discuss that in these species and other Melipona species, most males are produced during short pe- 
riods and they called them male-producing periods. These periods are not necessarily synchronous among colonies, because each colony has its dynamics in the production of reproductives. Over a short period of time, some workers lay reproductive eggs along with haploid eggs laid by the mated queen (Velthuis et al., 2005). But similar to what was found by van Benthem et al. (1995) in P. remota, the great majority of males are produced by the mother queen of the colony. The same was detected by Tóth et al. (2002) with DNA microsatellite analysis, which showed that a small proportion of males were workers' sons in some stingless bee species. These males were detected in one colony among seven that they sampled. Thus, both methodologies, based on direct observation and on molecular techniques, indicated that the workers contribute to male production, but in a relatively inconspicuous way (Velthuis et al., 2005).

Because these combs had a lot of males, low percentages of workers were observed, indicating that the colony invests less in workers when many males are produced (Santos-Filho et al., 2006).

\section{ACKNOWLEDGMENTS}

We dedicate this article to Dr. Warwick E. Kerr who has devoted his life to study stingless bees and contributed significantly to our knowledge about these fascinating insects. We thank FAPESP (\#05/58093-8; \#04/15801-0) and CNPq (\#370824/2000-8; \#311381/2006-5) for financial support. We also thank Dr. Tom Wenseleers and the anonymous referees for comments and language improvement.

\section{REFERENCES}

Alves DA and Imperatriz-Fonseca VL (2005). One Year-study on the Production of Sexuals in a Stingless Bee Species, Schwarziana quadripunctata (Lepeletier, 1836) (Hymenoptera: Apidae: Meliponini). In: The Annual Meeting of the Association for Tropical Biology and Conservation. Handbook of Association for Tropical Biology and Conservation, Uberlândia, 103.

Bego LR (1982). On social regulation in Nannotrigona (Scaptotrigona) postica Latreille, with special reference to male production cycles (Hym., Apidae, Meliponinae). Bol. Zool. Univ. S. Paulo 7: 181-196.

Bego LR (1990). On social regulation in Nannotrigona postica Latreille, with special reference to productivity of colonies (Hymenoptera, Apidae, Meliponinae). Rev. Bras. Entomol. 34: 721-738.

Bego LR and Camargo CA (1984). On the occurrence [sic] of giant males in Nannotrigona (Scaptotrigona) postica Latreille (Hymenoptera, Apidae, Meliponinae). Bol. Zool. Univ. S. Paulo 8: 11-16.

Beig D (1972). The production of males in queenright colonies of Trigona (Scaptotrigona) postica. J. Apic. Res. 11: 33-39.

Cabral GCP and Imperatriz-Fonseca VL (2007). Produção de Machos, Rainhas e Operárias em Colônias de Nannotrigona testaceicornis Lepeletier Durante a Primavera e Verão (Apidae, Meliponinae). In: Anais do VIII Congresso de Ecologia do Brasil, Caxambu, 1-2.

Camargo JMF (1974). Notas sobre a morfologia e biologia de Plebeia (Schwarziana) quadripunctata quadripunctata (Hymenoptera, Apidae, Meliponinae). Stud. Entomol. 17: 433-470.

Camillo C (1971). Estudos adicionais sobre os zangões de Trigona (Friesella) schrottkyi (Hymenoptera, Apidae). Cienc. Cult. 23: 273.

Chinh TX and Sommeijer MJ (2005). Production of sexuals in the stingless bee Trigona (Lepidotrigona) ventralis flavibasis Cockerell (Apidae, Meliponini) in northern Vietnam. Apidologie 36: 493-503.

Francisco FO, Nunes-Silva P, Francoy TM, Wittmann D, et al. (2008). Morphometrical, biochemical and molecular tools for assessing biodiversity. An example in Plebeia remota (Holmberg, 1903) (Apidae, Meliponini). Insectes Soc. 55: 231-237.

Grosso AF, Bego LR and Martinez AS (2000). The production of males in queenright colonies of Tetragonisca angustula angustula (Hymenoptera, Meliponinae). Sociobiology 35: 475-485.

Hamilton WD (1964a). The genetical evolution of social behaviour. I. J. Theor. Biol. 7: 1-16.

Genetics and Molecular Research 8 (2): 672-683 (2009)

CFUNPEC-RP www.funpecrp.com.br 
Hamilton WD (1964b). The genetical evolution of social behaviour. II. J. Theor. Biol. 7: 17-52.

Hilário SD (2005). Atividade de Vôo e Termorregulação de Plebeia remota (Holmberg, 1903) (Hymenoptera, Apidae, Meliponini). Doctoral thesis, Instituto de Biociências, USP, São Paulo.

Imperatriz-Fonseca VL, Cruz-Landim C and Silva de Moraes RLM (1997). Dwarf gynes in Nannotrigona testaceicornis (Apidae, Meliponinae, Trigonini). Behaviour, exocrine gland morphology and reproductive status. Apidologie 28: 113-122.

Juliani L (1967). A descrição do ninho e alguns dados biológicos sobre a abelha Plebeia julianii Moure, 1962 (Hymenoptera, Apoidea). Rev. Bras. Entomol. 12: 31-58.

Kerr WE (1950). Genetic determination of castes in the genus Melipona. Genetics 35: 143-152.

Koedam D, Contrera FAL and Imperatriz-Fonseca VL (1999). Clustered male production by workers in the stingless bee Melipona subnitida Ducke (Apidae, Meliponinae). Insectes Soc. 46: 387-391.

Mehdiabadi NJ, Reeve HK and Mueller UG (2003). Queens versus workers: sex-ratio conflict in eusocial Hymenoptera. Trends Ecol. Evol. 18: 88-93.

Oster GF and Wilson EO (1978). Caste and Ecology in the Social Insects. 1st edn. Princeton University Press, New York.

Patrício EFLRA and Imperatriz-Fonseca VL (2004). S.E.M. and GC-MS studies of Plebeia remota (Hymenoptera, Meliponini). In: Proceedings of 8th IBRA International Conference on Tropical Bees and VI Encontro sobre Abelhas, Ribeirão Preto, 739.

Peters JM, Imperatriz-Fonseca VL, Queller D, Roubik DW, et al. (1999). Mate number, kin selection and social conflicts in stingless bees and honeybees. Proc. R. Soc. Lond. B 22: 379-384.

Ratnieks FLW (1993). Egg-laying, egg-removal, and ovary development by workers in queenright honey bee colonies. Behav. Ecol. Sociobiol. 32: 191-198.

Ratnieks FLW (2001). Heirs and spares: caste conflict and excess queen production in Melipona bees. Behav. Ecol. Sociobiol. 50: 467-473.

Reuter M and Keller L (2001). Sex ratio conflict and worker production in eusocial Hymenoptera. Am. Nat. 158: 166-177.

Ribeiro MF and Alves DA (2001). Size variation in Schwarziana quadripunctata queens (Hymenoptera, Apidae, Meliponini). Rev. Etol. 3: 59-65.

Ribeiro MF, Imperatriz-Fonseca VL and Santos-Filho PS (2003a). Exceptional high queen production in the Brazilian stingless bee Plebeia remota. Stud. Neotrop. Fauna Environm. 38: 111-114.

Ribeiro MF, Imperatriz-Fonseca VL and Santos-Filho PS (2003b). A Interrupção da Construção de Células de Cria e Postura em Plebeia remota (Holmberg, 1903) (Hymenoptera, Apidae, Meliponini). In: Apoidea Neotropica: Homenagem aos 90 Anos de Jesus Santiago Moure (Melo GAR and Alves dos Santos I, eds.). Editora UNESC, Criciúma, 177-188.

Ribeiro MF, Wenseleers T, Santos-Filho PS and Alves DA (2006). Miniature queens in stingless bees: basic facts and evolutionary hypotheses. Apidologie 37: 191-206.

Sakagami SF (1982). Stingless Bees. In: Social Insects (Hermann HR, ed.). Academic Press Inc., New York, 272-423.

Sakagami SF, Beig D, Zucchi R and Akahira Y (1963). Occurrence of ovary-developed workers in queenright colonies of stingless bees. Rev. Bras. Biol. 23: 115-129.

Santos-Filho PS, Alves DA, Eterovic A, Imperatriz-Fonseca VL, et al. (2006). Numerical investment in sex and caste by stingless bees (Apidae: Meliponini): a comparative analysis. Apidologie 37: 207-221.

Strassmann JE (2001). The rarity of multiple mating by females in the social Hymenoptera. Insectes Soc. 48: 1-13.

Tóth E, Strassmann JE, Nogueira-Neto P, Imperatriz-Fonseca VL, et al. (2002). Male production in stingless bees: variable outcomes of queen-worker conflict. Mol. Ecol. 11: 2661-2667.

Tóth E, Queller DC, Dollin A and Strassmann JE (2004). Conflict over male parentage in stingless bees. Insectes Soc. 51: 1-11.

van Benthem FDJ, Imperatriz-Fonseca VL and Velthuis HHW (1995). Biology of the stingless bee Plebeia remota (Holmberg): observations and evolutionary implications. Insectes Soc. 42: 71-87.

Velthuis HHW, Koedam D and Imperatriz-Fonseca VL (2005). The males of Melipona and other stingless bees, and their mothers. Apidologie 36: 169-185.

von Ihering H (1903). Biologie der stachellosen bienen brasiliens. Zool. Jahrb. Syst. Oekol. Geogr. der Tiere 19: 179-287.

Wenseleers T, Ratnieks FL and Billen J (2003). Caste fate conflict in swarm-founding social hymenoptera: an inclusive fitness analysis. J. Evol. Biol. 16: 647-658.

Wenseleers T, Ratnieks FL, Ribeiro MF, Alves DA, et al. (2005). Working-class royalty: bees beat the caste system. Biol. Lett. 1: 125-128. 